\title{
Craspedacusta sowerbii, Lankester 1880 - population dispersal analysis using COI and ITS sequences
}

\author{
Gisela B. FRITZ, Martin PFANNKUCHEN, Andy REUNER, Ralph O. SCHILL and Franz BRÜMMER* \\ Universität Stuttgart, Biological Institute, Department of Zoology, 70569 Stuttgart, Germany \\ *e-mail corresponding author: franz.bruemmer@bio.uni-stuttgart.de
}

\begin{abstract}
Craspedacusta sowerbii (Hydrozoa, Limnomedusae, Olindiidae) is a freshwater jellyfish, which was discovered in England in 1880. Although thought to originate in South America, it became obvious that the species is native to the Yangtze River system in China. It has spread from China into lakes all over the world. Many different species, variations and sub-species have been described based on morphological characters. Specimens discovered in North America were described as separate species, as morphological differences appeared to be significant compared to European specimens. Even within Europe, differences were assumed to be obvious. Up to this point, three valid species are published; others are considered by various scientists to be true species as well, but mostly are recognized as variations. To obtain further insight into population dynamics of C. sowerbii as well as molecular information on the species itself, sequences of internal transcribed spacers (ITS) and cytochrome oxidase subunit I (COI) have been used to analyze specimens collected in Germany and Austria. These sequences have been compared to sequences published of different Chinese Craspedacusta species and variations. In addition, morphological descriptions were compared. For the COI sequences, we found uniformity throughout the complete set of samples. However, no comparisons could be made, as no data had been published on COI of Chinese specimens. ITS1, 5.8S and ITS2, including partial 18S and 28S, sequences, were almost uniform within the German populations, showing only minor base pair exchanges. However, comparisons to Chinese organisms indicated, that the investigated sequences of C. sowerbii from Germany and Austria are similar, although not identical in morphology, to Craspedacusta sowerbii var. kiatingi from China. Overall our data support the assumption that there are three valid species, with the possibility of $\mathrm{C}$. ziguiensis being a fourth one, and several, morphological quite different sub-species or variations of the freshwater jellyfish C. sowerbii.
\end{abstract}

Key words: Cnidaria, cytochrome oxidase, Hydrozoa, internal transcribed spacers, Limnomedusa

\section{INTRODUCTION}

Craspedacusta sowerbii, Lankester 1880 is a freshwater jellyfish within the family Olindiidae (Hydrozoa, Limnomedusae). Originating from the Yangtze River area in China (Kramp 1950, 1961), it has been introduced to many freshwater habitats worldwide (Acker \& Muscat 1976; Boothroyd et al. 2002; Pennak 1956; Silva \& Roche 2007). Although several freshwater species within the genus Craspedacusta exist, only $C$. sowerbii exhibits such a worldwide distribution. Means of distribution are less likely the short-lived medusa stage but more likely the minute polyp or any of the vegetative reproductive phases, such as frustules (Dejdar 1934; Reisinger 1957). After its discovery and subsequent first scientific description in England in 1880 (Lankester 1880), many reports of its occurrence were published within the following decades. However, it was impossible to reconstruct how the jellyfish was distributed and if there have been singular or multiple introduction events. Within recent years large numbers of new findings have been collected. Overall, C. sowerbii occurs in nearly all regions of Germany and new locations can be added on a regular basis (Fritz et al. 2007).
Several Craspedacusta species, subspecies and variations have been described from China and one species from Japan. Although the systematics and phylogeny are not clear on these descriptions, it seems that up to this point there are three valid Craspedacusta species, i.e., C. sowerbii (Lankester 1880), C. iseanum (Oka \& Hara 1922), and C. sinensis (Gaw \& Kung 1939). Others, described as new species, are C. brevenima (He $\& \mathrm{Xu}$ 2002), C. chuxiongensis (He et al. 2000), C. sichuanensis (He \& Kou 1984), and C. ziguiensis (He \& Xu 1985). One species, C. vovasi, has been placed in a different genus by the authors themselves (Naumov \& Stepanjants 1971; Jankowki et al. 2001). In addition, several other subspecies and variations have been reported, although they have been subsequently described in other publications as species (He 2003).

Molecular markers have become a valuable tool to determine different level relationships amongst the Cnidaria including higher level taxa analyses as well as genera, species and population level studies (Collins et al. 2006; France \& Hoover 2002; Jankowski 2001; Jankowski et al. 2008; Parker et al. 1998). Although many observations on $C$. sowerbii have been reported over the years, nothing is known on the population dynamics and potential temporal or spatial dynamics of introduction events. 
Tab. 1. Sampling locations of freshwater jellyfish medusae in quarry lakes in Germany and Austria including accession numbers for COI/ITS.

\begin{tabular}{|c|c|c|c|c|}
\hline Lake & Location & Collection date & $\begin{array}{l}\text { Sequence } \\
\text { analysys }\end{array}$ & $\begin{array}{c}\text { Accession number } \\
\text { COI/ITS }\end{array}$ \\
\hline Flückiger See & Freiburg, Baden-Wuerttemberg & Oct. 2006 & COI, ITS & FJ423614/FJ423625 \\
\hline Diezsee & Limburg, Rheinland-Pfalz & Sept. 2006 & COI, ITS & FJ423623/FJ423620 \\
\hline Canyon Süplingen & Süplingen-Haldensleben, Saxony-Anhalt & Aug. 2006 & COI, ITS & FJ423618FJ423628 \\
\hline Schönbach & Herborn, Hessen & Aug. 2006 & COI, ITS & FJ423613/FJ423624 \\
\hline Klingenberg & Langenfeld, Northrhine-Westphalia & Aug. 2006 & COI, ITS & FJ423617/FJ423627 \\
\hline Hohwiesensee & Ketsch, Baden-Wuerttemberg & Aug.2006 & COI, ITS & FJ423619/FJ423629 \\
\hline Matschelsee & Kürzell, Baden-Wuerttemberg & Oct. 2006 & COI, ITS & FJ423615/FJ423626 \\
\hline Löbejun & Löbejun, Saxony Anhalt & Aug. 2006 & COI, ITS & FJ423616/FJ423633 \\
\hline Streitköpfle & Linkenheim-Hochstetten, Baden-Wuerttemberg & Aug.2007 & ITS & $-/$ FJ423631 \\
\hline Lußhardtsee & Kronau, Baden-Wuerttemberg & Aug. 2007 & ITS & -/FJ423622 \\
\hline Gänsedrecksee & Speyer, Rheinland-Pfalz & Aug. 2007 & ITS & -/FJ423621 \\
\hline Willersinn II & Karlsruhe, Baden-Wuerttemberg & Aug. 2007 & ITS & -/FJ423630 \\
\hline Alte Donau/ Danube & Vienna, Austria & unknown & ITS & -/FJ423632 \\
\hline
\end{tabular}

Therefore, this study was conducted to obtain molecular information on $C$. sowerbii populations within Germany and Austria (for easy reading called "German" from now on) using internal transcribed spacers (ITS) and cytochrome oxidase subunit I (COI). The sequence information was used to obtain more insight on the usefulness of COI for species barcoding (Hebert \& Gregory 2005; Hebert et al. 2003) as well as potential information on population dispersal and introduction events of $C$. sowerbii. We also gained a deeper insight into the systematic and phylogenetic positioning of the German freshwater jellyfish population within the Craspedacusta group.

\section{METHODS}

\subsection{Specimen collection and preservation}

Jellyfish medusae were collected from eleven different lakes within Germany as well as one water body in Austria (Tab. 1). The specimens were collected by SCUBA divers, who participated in a project using laymen to obtain scientific data on the distribution of aquatic neobiota. Identification was reliable as there are no other hydrozoans with free swimming medusae stages in Europe. Immediately after collection, the specimens were preserved in $99 \%$ Ethanol molecular biology grade (Roth, Karlsruhe, Germany) and stored at $4{ }^{\circ} \mathrm{C}$. Prior to DNA extraction ethanol was removed by placing specimens in a dilution series $(75 \%, 50 \%, 30 \%$, $10 \%$ ethanol in water and pure water) for $10 \mathrm{~min}$ at each step and two times $30 \mathrm{~min}$ in pure water.

\subsection{DNA extraction and $P C R$}

DNA was obtained by using a DNA preparation kit (Macherey-Nagel, Düren, Germany) according to the manufacturer's instructions. One complete medusa was used for each extraction. DNA concentration was measured using a NanoDrop ${ }^{\circledR}$ Spectrophotometer ND-1000 (Peqlab, Erlangen, Germany).

An approximately 600 base pair (bp) partial sequence of the cytochrome oxidase subunit I (COI) was amplified using the forward primer primers 5'GGTCAACAACAAATCATAAAGATATTGG-3' and the reverse primer 5'-TAAACTTCAGGGTGACCAAAAAATCA-3' (Folmer et al. 1994). Amplification was performed in $20 \mu \mathrm{L}$ total reaction volume with $200 \mathrm{ng}$ template DNA, $1 \mathrm{U}$ Taq polymerase (TaKaRa BIO INC., Shiga, Japan), 3.9 mmol L ${ }^{-1} \mathrm{MgCl}_{2}, 0.2 \mathrm{mmol} \mathrm{L}{ }^{-1}$ $\mathrm{dNTP}$, and $2 \mathrm{mmol} \mathrm{L}^{-1}$ of each oligonucleotide primer. The COI sequence was amplified with an initial denaturation step of $5 \mathrm{~min}$ at $94{ }^{\circ} \mathrm{C}$, followed by five cycles of $1 \mathrm{~min}$ at $94{ }^{\circ} \mathrm{C}, 1.5 \mathrm{~min}$ at $45^{\circ} \mathrm{C}$ and $1.5 \mathrm{~min}$ at $72{ }^{\circ} \mathrm{C} ; 35$ cycles of $1 \min 94{ }^{\circ} \mathrm{C}, 1.5 \mathrm{~min}$ at $50^{\circ} \mathrm{C}, 1$ min at $72{ }^{\circ} \mathrm{C}$ and a final extension of 5 min at $72{ }^{\circ} \mathrm{C}$. An $800 \mathrm{bp}$ partial sequence of the ribosomal DNA was amplified using the primers forward primer 5'CCCTTTGTACACACCGCCCGTCGCT-3' and the reverse primer 5'-CTTTGGGCTGCAGTCCCAAGCAACCCGACTC-3' (Odorico \& Miller 1997). This partial sequence included parts of the $18 \mathrm{~S}$ rDNA and $28 \mathrm{~S}$ rDNA, the complete ITS1 and ITS2 regions as well as the 5.8S rDNA region. The PCR reaction mixture was equivalent to the mixture for the amplification of the COI sequence (see above) in a final volume of $20 \mu \mathrm{L}$. An initial denaturation at $96{ }^{\circ} \mathrm{C}$ for 3 min was followed by 30 cycles $\left(95^{\circ} \mathrm{C}\right.$ for $1 \mathrm{~min}, 52^{\circ} \mathrm{C}$ for $30 \mathrm{~s}, 72^{\circ} \mathrm{C}$ for $1 \mathrm{~min}$ ) and a final extension at $72{ }^{\circ} \mathrm{C}$ for $7 \mathrm{~min}$.

\subsection{Cloning and DNA sequencing}

PCR-products were cleaned using Nucleo-Spin ${ }^{\mathbb{R}}$ Extract II kit (Macherey-Nagel) following the manufacturer's instructions. Subsequently they were ligated into $\mathrm{pCR}^{\circledR} 4$-TOPO vector (Invitrogen, Carlsbad, USA) and introduced into competent Escherichia coli One Shot ${ }^{\mathbb{B}}$ TOP10 cells (Invitrogen) following the manufacturer's instructions. Plasmid DNA was subsequently isolated from cultures with the NucleoSpin ${ }^{\circledR}$ Plasmid Kit (Macherey-Nagel). Insert sizes were verified performing an EcoR1 digestion and subsequent agarose gel electrophoresis.

Sequences of interest ( $800 \mathrm{bp}$ ) were sequenced with M13forward as well as an M13reverse primer by 
Tab. 2. Distance matrix of the given 800 bp including partial 18S, ITS1, 5.8S, ITS2 and partial 28S regions of available Craspedacusta species. Identical sequences of German and Austrian samples (distance $=0-0.1 \%$ ) have been combined to C. sowerbii. Ranges are given for multiple entries per species. Numbers in brackets indicate number of different sequences used, no number indicates single sample.

\begin{tabular}{|c|c|c|c|c|c|c|c|c|c|c|}
\hline & 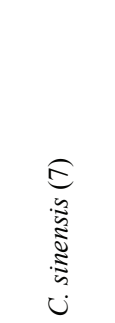 & 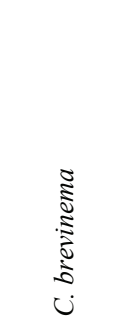 & 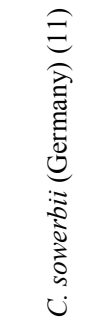 & 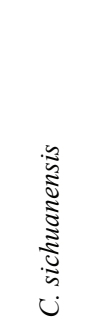 & 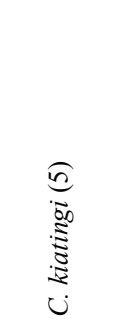 & 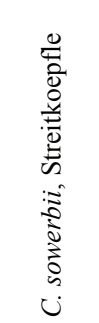 & 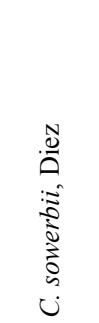 & 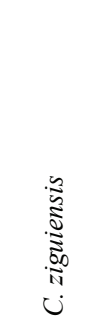 & 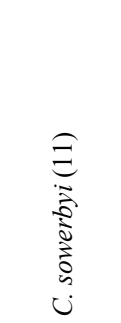 & 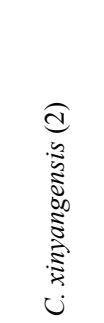 \\
\hline C. sinensis (7) & $0.1-1.6$ & $0.1-1.4$ & $9.1-10.2$ & $8.9-10$ & $8.9-10.2$ & $8.9-10$ & $9-10$ & $10-11.1$ & 9.9-11.9 & $9.9-11.4$ \\
\hline C. brevinema & $0.1-1.4$ & - & $9.1-9.3$ & 9.1 & $8.9-9.1$ & 9.1 & 9.1 & 10.2 & $10.9-11.3$ & 10.9 \\
\hline C. sowerbii (11) & $9.1-10.2$ & $9.1-9.3$ & $0-0.1$ & $0-0.1$ & $0-0.4$ & 0 & $0-0.1$ & $3.1-3.2$ & $8.4-8.7$ & $8.4-8.7$ \\
\hline C. sichuanensis & $8.9-10$ & 9.1 & $0-0.1$ & - & $0-0.3$ & 0 & 0 & 3.1 & $8.2-8.7$ & $8.4-8.5$ \\
\hline C. kiatingi (5) & $8.9-10.2$ & $8.9-9.1$ & $0-0.4$ & $0-0.3$ & $0-0.3$ & $0-0.3$ & $0-0.3$ & $3.1-3.3$ & $8.4-8.8$ & $8.2-8.5$ \\
\hline C. sowerbii Streitköpfle & $8.9-10$ & 9.1 & 0 & 0 & $0-0.3$ & - & 0 & 3 & $8.4-8.7$ & $8.4-8.5$ \\
\hline C. sowerbii Diez & $9-10$ & 9.1 & $0-0.1$ & 0 & $0-0.3$ & 0 & - & 3.1 & $8.2-8.7$ & $8.4-8.6$ \\
\hline C. ziguiensis & $10-11.1$ & 10.2 & $3.1-3.2$ & 3.1 & $3.1-3.3$ & 3 & 3.1 & - & $9.5-10$ & 9.7 \\
\hline C. sowerbyi (11) & $9.9-11.9$ & $10.9-11.3$ & $8.4-8.7$ & $8.2-8.7$ & $8.4-8.8$ & $8.4-8.7$ & $8.2-8.7$ & $9.5-10$ & $0-0.8$ & $0-0.9$ \\
\hline C. xinyangensis (2) & $9.9-11.4$ & 10.9 & 8.4-8.7 & $8.4-8.5$ & $8.2-8.5$ & $8.4-8.5$ & $8.4-8.6$ & 9.7 & $0-0.9$ & 0.4 \\
\hline
\end{tabular}

Macrogen (Seoul, Korea). Three clones of each individual specimen were sequenced with forward and reverse primers resulting in a total of six sequences.

\subsection{Sequence Analysis}

Sequences were edited and aligned manually as well as subsequently analyzed using the ARB (version 06.11.28) software package (Ludwig et al. 2004). Of each specimen three clones were sequenced with forward and reverse primers. For each specimen all six resulting sequences were aligned and resulted in one consensus sequence representing the majority decision where needed. The resulting consensus sequences together with available sequences from the databases (AY513614 - AY513641 and AY730675 - AY730678) were analyzed applying the Neighbor Joining, Maximum Likelihood and Maximum Parsimony algorhythms. Of these three analyses a strict consensus tree was constructed (Ludwig et al. 1998).

\subsection{Database deposition}

The resulting nucleotide sequence data reported in this paper have been deposited in the GenBank nucleotide sequence database with accession numbers FJ423613 through FJ423633 (Tab. 1).

\section{RESULTS}

\subsection{Cytochrome oxidase I (COI)}

All resulting COI sequences (FJ423613 through FJ423620) from all tested specimens were identical. No comparisons with Craspedacusta sowerbii from other countries or other Craspedacusta species were possible, as no fresh material was available and no gene data were available in online data bases such as NCBI or Genbank.

\subsection{Internal transcribed spacers (ITS)}

The ITS region included parts of the $18 \mathrm{~S}$ and $28 \mathrm{~S}$ regions, the $5.8 \mathrm{~S}$ and the two ITS regions I and II. The alignment used for analysis and sequence comparison included 1,091 positions. Amongst the German specimens, minor differences were found. C. sowerbii from Löbejün showed a 9 bp insertion, which can be found identically in C. ziguiensis from China, at position 299307. None of the other analyzed sequences exhibited this insertion. As this insertion can be suspected to be a single event, we did treat it as a single position in further analysis to avoid overestimation of this event. Single nucleotide insertions at several positions result in the slightly elevated similarity of the samples from Diezsee, Klingenberg and Streitköpfle to the Chinese C. kiatingi, as compared to the rest of the German populations. Compared with sequences from Chinese specimens obtained from the NCBI database more differences could be found and are represented in the resulting distance matrix shown in table 2. The corresponding strict consensus representation of Neighbour Joining, Maximum Likelihood and Maximum Parsimony analyses is shown in figure 1. Three clusters of Craspedacusta species are found within the sequences from the Yangtze population, with the German population being part of the "kiatingi" cluster.

\subsection{Morphology}

Data have been compiled from different sources to compare morphological features of the observed species and subspecies (Lankester 1880; Dejdar 1934; Kramp 


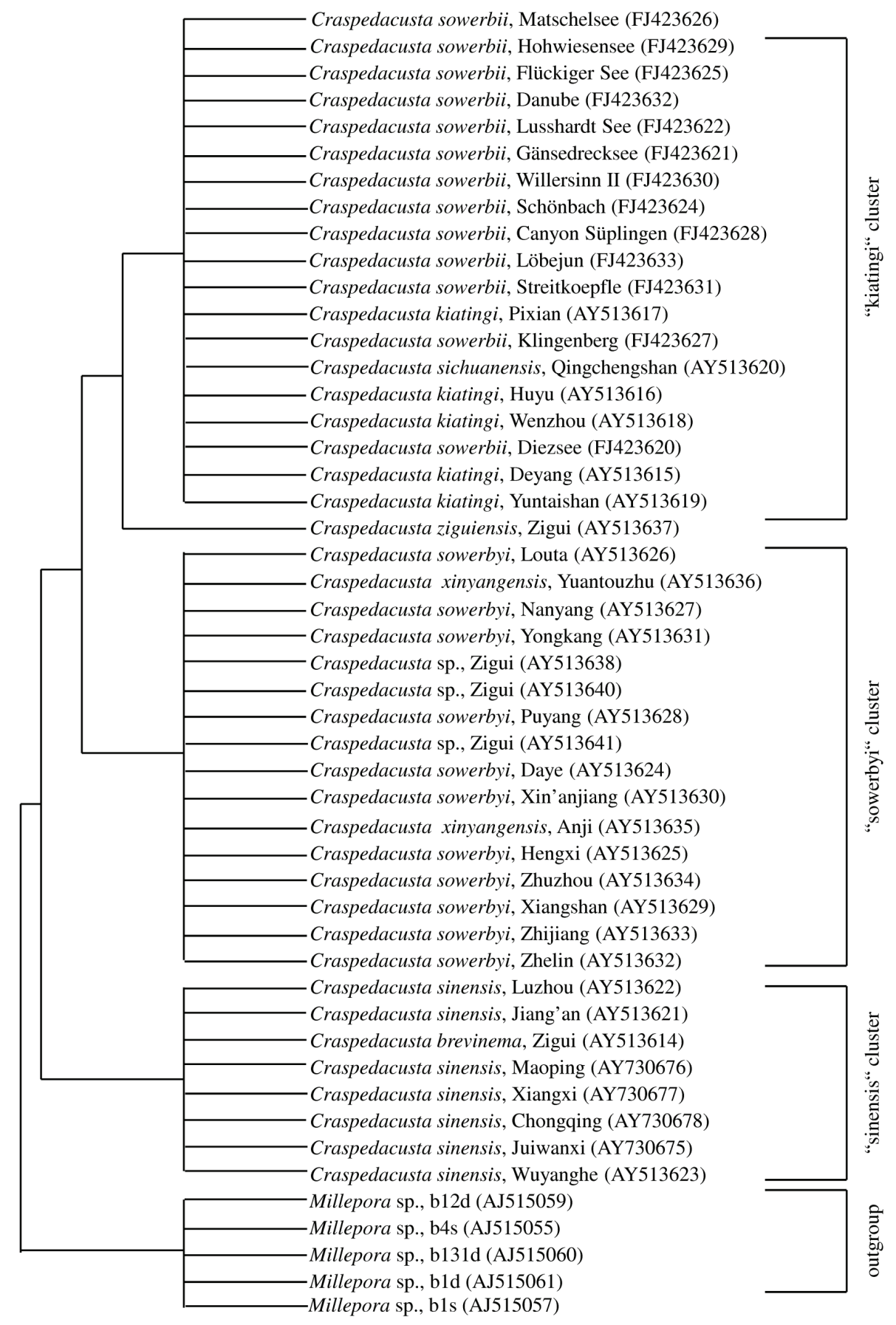

Fig. 1. A strict consensus representation of the Neighbor Joining, Maximum Likelihood and Maximum Parsimony analyses of the given 800 bp including partial 18S, ITS1, 5.8S, ITS2 and partial 28S regions of available Craspedacusta including Millepora sp. as next available relatives (outgroup).

1950, 1961; He \& Xu 1985; 2002, 2003; He et al. 2000; Jankowski 2001). Although C. sowerbii described in Germany and other European countries look totally different from $C$. kiatingi, newly budded $C$. sowerbii look exactly as the described $C$. sowerbyi var. kiatingi. (Chinese specimens found in GenBank have been written with $-y i$. For differentiation purposes between Chinese and German specimens we kept the $-y i$ spelling for the
Chinese, and the -ii for the German specimens.) The umbrella is not flattened, but hemispherical and the gonads are small and pocket-like. On the other hand all mature German and Austrian specimens used for this study, as well as most of the worldwide described specimens look with some variations similar to $C$. sowerbyi specimens. 


\section{DISCUSSION}

Although, described and discovered outside of China for the first time in 1880 (Lankester 1880), it is not known when the freshwater jellyfish was actually introduced into worldwide aquatic systems. The rapidly incoming reports after the first description indicate that the jellyfish may have been already present for quite some time, or at least since exotic ornamental aquatic plants, its potential source of transportation, were used in aquaria and parks. Still, new occurrences of the jellyfish are discovered within in Germany (Fritz et al. 2007) and worldwide (Arbaèiauskas \& Lesutienë 2005, PérezBote et al. 2006, Saadalla 2006). It is difficult to determine whether these are new introductions, local dispersal or just new observations. The increasing number could be due to several, not necessarily independent, factors i) The distribution is in fact increasing, ii) the medusae only occur for a short period of time during summer and need to be looked for or are found accidentally, iii) the polyp stage is minute and usually not detected but might have existed within a habitat long before the conditions were optimal for medusa formation and iv) increasing, recreational, aquatic activities such as SCUBA diving lead to an increase in observations. After the description of multiple sub-species and species, it seemed to be interesting to look into the location of origin, compare described species and elucidate the implications for introduction events.

Comparing morphological features, C. sowerbii found in Germany looks very different to $C$. sowerbii var. kiatingi, which is named as species by $\mathrm{He}(\mathrm{He}$ 2003) and was described as variation at first description (Gaw \& Kung 1939). The very small gonads, like in $C$. ziguiensis, make it difficult to see the similarity to $C$. sowerbii, let alone the differences in nematocyst arrangement. However, due to its similarity within the ITS region and morphological comparisons and discussions (Kramp 1950), the data support the status of C. $s$. var. kiatingi as a subspecies and indicate the origin of freshwater jellyfish found within Germany to be located in the Kiating area. The sub-species Craspedacusta sowerbyi xinyangensis, (He 1980) is indeed a form of $C$. sowerbii. On the other hand, the molecular data indicate that $C$. brevinema is a variation of $C$. sinensis, which also supports the fact that $C$. sinensis is a separate species. In addition, $C$. ziguiensis may be a separate species as indicated by a difference of approximately $3 \%$ in the distance matrix. This is also supported by $\mathrm{mt} 16 \mathrm{~S}$ and SSU analyses (Collins et al. 2008).

C. sichuanensis has morphological features similar to $C$. sinensis, however, some like $C$. iseanum (Jankowski 2001). The ITS sequences suggest genetic similarity with C. s. var kiatingi (Bouillon \& Boero 2000; Jankowski 2001). This is supported by our data, however, a distance of $3.1 \%$ and hence, $5.3 \%$ to the Chinese $C$. sowerbyi might indicate a separate variation or subspecies. Sequences of the newly described species
C. chuxiongensis (He 2003), have not been made publicly available yet and could not be compared. However, based on the data shown above, it is likely to be yet another variation of $C$. sowerbii. As mentioned by other scientists (Kramp 1950; Bouillon \& Boero 2000; Jankowski 2001), our data support the fact that all Chinese "species", with the exception of $C$. sinensis, seem to be variations of either the latter or $C$. sowerbii. Hence at least three clusters or genetically separate groups of Craspedacusta seem to exist in the Yangtze River system. The "kiatingi cluster", the "sinensis" cluster and a third cluster comprising C. sowerbyi species. Regarding the ITS sequences, the German populations show a high genetic similarity to the "kiatingi" cluster, and hence most probably originated from $C$. kiatingi.

Craspedacusta exhibit a highly variable morphology, which has been already shown, when specimens were described as new species wherever $C$. sowerbii was observed for the first time (Browne 1906; Potts 1906; Roch 1924). Even specimens occupied one large, but interconnected river system show a huge variability as is seen in the populations observed and described from the Yangtze River system. Not only geography seems to play an important role but also, of course, the conditions of abiotic factors during the development of medusae (Kramp 1950). In addition, as so often, specimens are not described when newly collected and unpreserved. Handling and fixation methods also might lead to different conclusions as specimens are, for example, contracted when preserved and, subsequently, exhibited supposedly obvious differences (Dejdar 1934; Kramp 1950). One important feature, the shape of nematocysts as well as their arrangement in warts, is given a lot of attention although some investigations show difficulties in actually finding these differences when comparing more than one specimen and using fresh material (Dejdar 1934). Nematocysts indeed have taxonomic value at species level, however, it has to be considered that size, types and location can differ within a specimen depending on its stage of metagenesis (Östman 2000). As a result from these observations, many morphological features, which lead to the differentiation between different species, are questionable going conform with other authors (Dejdar 1934; Kramp 1950). And hence the molecular data not necessarily contradict morphological information, but rather ask for re-evaluation of some morphological investigations.

\section{CONCLUSIONS}

In general, the COI sequence is informative for barcoding (Hebert et al. 2003; Hebert \& Gregory 2005) and therefore is a useful tool for some groups. However, earlier studies have shown that it is not useful for all taxonomic groups where it works for some species and does not for others (Heim et al. 2007a, Heim et al. 2007b). Even within the Cnidaria, COI evolved differently, leading to differences between the Scyphozoa, 
Anthozoa and Hydrozoa (Huang et al. 2008), with more variation in the first group. It would be useful at this point to investigate the COI sequences of different species of Craspedacusta as well as comparing the sequences of different variations. Among the specimens found in Germany, which presumably belong to the very same species, no genetic variations were found. Hence the investigated region of the COI gene, bears no information on the population level whatsoever, but it is consistent (identical) within the German population of C. sowerbii. Still the German lakes could be regarded as hosting just one, genetically connected population of $C$. sowerbii. At least the German population only consists of one single species. Further investigation including COI information from more populations and species will elucidate the phylogenetic information content of COI sequences within freshwater medusae.

The ITS sequences again were identical throughout the samples from German lakes analyzed in this investigation. However they were slightly different from those C. sowerbyi sequences originating from China. These differences lay well within the ones observed between different Chinese populations of $C$. sowerbyi and $C$. kiatingi. This observation not only leads to the conclusion that $C$. sowerbii and $C$. kiatingi are in fact the same species, but also shows, that the sequences ITS1, 5,8S rDNA and ITS2 together allow the discrimination between genetically separated populations. We hence conclude, that the German population of $C$. sowerbii can be regarded as one population, presumably with some extent of genetic exchange or just too young to undergo diversification. It originated from the Chinese population of C. kiatingi and was shortly after invasion genetically separated from the original population in China. We furthermore suppose $C$. kiatingi to be renamed as $C$. sowerbii var. kiating due to sequence identity or similarity. However, the investigation and analyses of additional molecular markers and the re-evaluation of the morphological details applying similar preservation and sampling techniques and comparing similar stages of metagenesis are necessary to verify the status of a species, as well as obtaining data on the populations' diversity. For further investigations on Craspedacusta species, we suggest to include morphological information on all stages of metagenesis, at least ITS sequences and additional molecular markers like preferably $\mathrm{COI}$ and $18 \mathrm{~S}$ rDNA.

\section{ACKNOWLEDGEMENTS}

The authors thank Jacqueline Hirsch for laboratory assistance and intensive discussions. Thanks also go the laboratory assistant Inga Polle. This research would not have been possible without the help of many SCUBA divers, who participated in the project "NEOBIOTA" of the German Underwater Association (VDST e. V.). Special thanks to Dieter Kaltenegger for providing the Austrian specimens. This study was financed by the
Landesbank Baden-Württemberg (LBBW), Stuttgart, Germany.

\section{REFERENCES}

Acker, T.S. \& A.M. Muscat. 1976. Ecology of Craspedacusta sowerbii Lankester, a freshwater hydrozoan. Am. Midl. Nat., 95: 323-336.

Arbaèiauskas, K. \& J. Lesutienë. 2005. The freshwater jellyfish (Craspedacusta sowerbii) in Lithuanian waters. Acta Zool. Lit., 15: 60-63.

Boothroyd, I.K.G., M.K. Etheredge \& J.D. Green. 2002. Spatial distribution, size structure, and prey of Craspedacusta sowerbyi Lankester in a shallow New Zealand lake. Hydrobiologia, 468: 23-32.

Bouillon, J. \& F. Boero. 2000. Synopsis of the families and genera of the hydromedusae of the world, with a list of the worldwide species. Thal. Sal., 24: 47-296.

Browne, E.T. 1906. On the freshwater medusa liberated Microhydra ryderi, Potts, and a comparison with Limnocodium. Q. J. Microsc. Sci., 50: 635-645, + pl 37.

Collins, A.G., P. Schuchert, A.C. Marques, T. Jankowski, M. Medina \& B. Schierwater. 2006. Medusozoan phylogeny and character evolution clarified by new large and small subunits rDNA data and an assessment of the utility of phylogenetic mixture models. Syst. Biol., 55: 97-115.

Collins, A.G., B. Bentlage, A. Lindner, D. Lindssay, S.H.D. Haddocks, G. Jarms, J.I. Norenburg, T. Jankowski \& P. Cartwright. 2008. Phylogenetics of Trachylina (Cnidaria: Hydrozoa) with new insights on the evolution of some problematical taxa. J. Mar. Biol. Assoc. UK, Doi: $10.1017 / \mathrm{S} 0025315408001732$.

Dejdar, E. 1934. Die Süßwassermeduse Craspedacusta sowerbii Lankester in monographischer Darstellung. Z. Morphol. Ökol. Tiere, 28: 595-691.

Folmer, O., M. Black, W. Hoeh, R. Lutz \& R. Vrijenhoek. 1994. DNA primers for amplification of mitochondrial cytochrome c oxidase subunit I frin diverse metazoan invertebrates. Mol. Mar. Bio. Biotechnol., 3: 294-299.

France, S.C. \& L.L. Hoover. 2002. DNA sequences of the mitochondrial COI gene have low levels of divergence among deep-sea octocorals (Cnidaria: Anthozoa). Hydrobiologia, 471: 149-155.

Fritz, G.B., R.O. Schill, M. Pfannkuchen \& F. Brümmer. 2007. The freshwater jellyfish Craspedacusta sowerbii Lankester, 1880 (Limnomedusa: Olindiidae) in Germany, with a brief note on its nomenclature. J. Limnol., 66: 5449.

Gaw, H.Z. \& L.H. Kung. 1939. Fresh-water medusae found in Kiating, Szechuen, China. Science, 90: 299.

He, Z.-W. 2003. A rivision of the genus Craspedacusta in China (Limnomedusae, Olindidae). Acta Zoo. Sinica, 28: 20-23.

He, Z.-W. \& R.-H. Xu. 1985. A new species of freshwater medusa from Hubei (Limnomedusae: Olindiadae). Acta Zoo. Sinica, 10: 341-343.

He, Z.-W. \& R.-H. Xu. 2002. A new species of freshwater medusa from China (Limnomedusae: Olindidae). Acta Zoo. Sinica, 27: 33-35.

He, Z.-W. \& R.-H. Xu. 2003. Distribution of Craspedacusta in China. Chin. J. Zool., 38: 79-80.

He, Z.w. \& Z.t. Kou. 1984. A new species of freshwater medusa from Sichuan. Acta Zoo. Sinica, 9: 340-342.

He, Z.-W., R.-H. Xu \& S.-M. Nie. 2000. A new species of freshwater medusa from Yunnan. Acta Zoo. Sinica, 25: 139-142.

Hebert, P.D.N. \& T.R. Gregory. 2005. The promise of DNA barcoding for taxonomy. Syst. Biol., 54: 852-859.

Hebert, P.D.N., S. Ratnasingham \& J.R. deWaard. 2003. Barcoding animal life: cytochrome c oxidase subunit 1 di- 
vergences among closely related species. P. Roy. Soc. Lond. B Bio., 270: S96-S99.

Heim, I., M. Nickel \& F. Brümmer. 2007a. Phylogeny of the genus Tethya (Tethyidae: Hadormerida: Porifera): molecular and morphological aspects. J. Mar. Biol. Ass. UK, 87: 1615-1627.

Heim, I., M. Nickel, B. Picton \& F. Brummer. 2007b. Description and molecular phylogeny of Tethya hibernica sp. nov. (Porifera, Demospongiae) from Northern Ireland with remarks on the European species of the genus Tethya. Zootaxa, 1-15.

Huang, D., R. Meier, P.A. Todd \& L. Ming Chou. 2008. Slow mitochondrial COI sequence evolution at the base of the metazoan tree and its implications for DNA barcoding. $J$. Mol. Evol., 66: 167-174.

Jankowski, T. 2001. The freshwater medusae of the world: A taxonomic and systematic literature study with some remarks on other inland water jellyfish. Hydrobiologia, 91-113.

Jankowski, T., A.G. Collins \& R.D. Campbell. 2008. Global diversity of inland water cnidarians. Hydrobiologia, 595: 35-40.

Kramp, P.L. 1950. Freshwater medusae in China. Proc. Zool. Soc. Lond., 120: 165-184.

Kramp, P.L. 1961. Synopsis of the Medusae of the world. Order Limnomedusae. J. Mar. Biol. Ass. UK, 40: 213-236.

Lankester, E.R. 1880. On a new Jellyfish of the Order Trachomedusae, living in fresh water. Science, 1: 34 .

Lankester, E.R. 1880. On Limnocodium (Craspedacusta) sowerbii, a new Trachomedusa inhabiting freshwater. $Q$. J. Microsc. Sci., 20: 351-371.

Lankester, E.R. 1880. On a new jellyfish of the order Trachomedusa, living in fresh water. Nature, 22: 147-148.

Ludwig, W., O. Strunk, S. Klugbauer, N. Klugbauer, M. Weizenegger, J. Neumaier, M. Bachleitner \& K.H. Schleifer. 1998. Bacterial phylogeny based on comparative sequence analysis. Electrophoresis, 19: 554-568.

Ludwig, W., O. Strunk, R. Westram, L. Richter, H. Meier, Yadhukumar, A. Buchner, T. Lai, S. Steppi, G. Jobb, W. Förster, I. Brettske, S. Gerber, A.W. Ginhart, O. Gross, S. Grumann, S. Hermann, R. Jost, A. König, T. Liss, R. Lüßmann, M. May, B. Nonhoff, B. Reichel, R. Strehlow, A. Stamatakis, N. Stuckmann, A. Vilbig, M. Lenke, T. Ludwig, A. Bode \& K.-H. Schleifer. 2004. ARB: a soft- ware environment for sequence data. Nucleic Acids Res., 32: $1363-1371$.

Naumov, D.V. \& S.D. Stepanjants. 1971. A new species of the genus Craspedacusta (Hydrozoa) from a sea lagoon. Zool. Zh., 50: 1094-1097.

Odorico, D.M. \& D.J. Miller. 1997. Variation in the ribosomal internal transcribed spacers and 5.8S rDNA among five species of Acropora (Cnidaria; Scleractinia): Patterns of variation consistent with reticulate evolution. Mol. Biol. Evol., 14: 465-473.

Oka, A. \& Hara. 1922. On a new species of Limnocodium from Japan. Annot. Zool. Jpn., 10:

Östman, C. 2000. A guideline to nematocyst nomenclature and classification, and some notes on the systematic value of nematocysts. Sci. Mar., 64: 31-46.

Parker, P.G., A.A. Snow, M.D. Schug, G.C. Booton \& P.A. Fuerst. 1998. What Molecules Can Tell Us about Populations: Choosing and Using a Molecular Marker. Ecology, 79: 361.

Pennak, R.W. 1956. The fresh-water jellyfish Craspedacusta in Colorado with some remarks on its ecology and morphological degeneration. T. Am. Microsc. Soc., 75: 324331.

Pérez-Bote, J.L., A. Muñoz, R. Morán, R. Roso \& A. José Romero. 2006. First record of Craspedacusta sowerbyi Lankester, 1880 (Cnidaria: Limnomedusae: Olindiidae) in the Proserpina Reservoir (Extremadura, SW Spain) with notes on their feeding habits. Belgian J. Zool., 136: 163166.

Potts, E. 1906. On the medusa of Microhydra inhabiting fresh water. Q. J. Microsc. Sci., 50: 623-633.

Reisinger, E. 1957. Zur Entwicklungsgeschichte und Entwicklungsmechanik von Craspedacusta (Hydrozoa, Limnotrachylina). Z. Morphol. Ökol. Tiere, 45: 656-698.

Roch, F. 1924. Microhydra germanica, eine neue Süßwassermeduse. Zool. Anz., 58: 131-136.

Saadalla, H.A.A. 2006. First record of the freshwater medusa Craspedacusta sp (Cnidaria, Hydrozoa) from an artificial lake in Baghdad, Iraq. Zool. Middle East, 107-110.

Silva, W.M. \& K.F. Roche. 2007. Occurrence of the freshwater jellyfish Craspedacusta sowerbii (Lankester, 1880) (Hydrozoa, Limnomedusae) in a calcareous lake in Mato Frosse do Sul, Brazil. Biota Neotropica, 7: 227-229.

Received: July 2008

Accepted: November 2008 